\title{
Sensitivity of DNA and Nucleotides to Oxidation by Permanganate and Hydrogen Peroxide
}

\author{
P. Sagelsdorff and W. K. Lutz \\ Institute of Toxicology, ETH and University of Zürich, CH-8603 Schwerzenbach, Switzerland
}

\section{Introduction}

For a number of cytotoxic and tumorigenic agents, active oxygen species such as hydroxyl radical are postulated to be responsible for indirect DNA damage (Cerutti 1981). Besides the formation of strand breaks, hydroxylation of DNA bases is assumed to occur, as shown earlier with ionizing radiation. It was the aim of this work to determine in vitro the DNA-damaging potency of hydrogen peroxide $\left(\mathrm{H}_{2} \mathrm{O}_{2}\right)$, and to compare that with the potency of the strong oxidant permanganate ion.

\section{Materials and Methods}

\section{Chemicals}

Chemicals were obtained from Merck (Darmstadt, FRG) or Fluka (Buchs, Switzerland) and were of analytical grade. Nucleotides and calf thymus DNA were from Sigma (St. Louis, Mo., USA); $\left[{ }^{14} \mathrm{C}\right]$ thymidine from the Radiochemical Center (Amersham, Buckinghamshire, GB).

\section{Oxidation of Nucleotides and DNA}

Oxidation with $\mathrm{KMnO}_{4}$ was performed at $0^{\circ} \mathrm{C}$ as described by Frenkel et al. (1981). The $\mathrm{H}_{2} \mathrm{O}_{2}$ reaction was carried out in $0.2 \mathrm{M}$ sodium phosphate, $\mathrm{pH} 7.8$, at $37^{\circ} \mathrm{C}$ with $25 \mu \mathrm{MFeCl}$. Single-stranded DNA was obtained by heat denaturation of double-stranded calf thymus DNA followed by rapid cooling at $-30^{\circ} \mathrm{C}$. The concentration of the oxidant is given in Table 1 and Figs. 1 and 2.

\section{Isolation of Oxidized $D N A$}

The reaction mixture was dialysed; DNA was precipitated with ethanol and stored at $-20^{\circ} \mathrm{C}$ overnight. The DNA was centrifuged for $20 \mathrm{~min}$ at $1000 \mathrm{~g}$, 


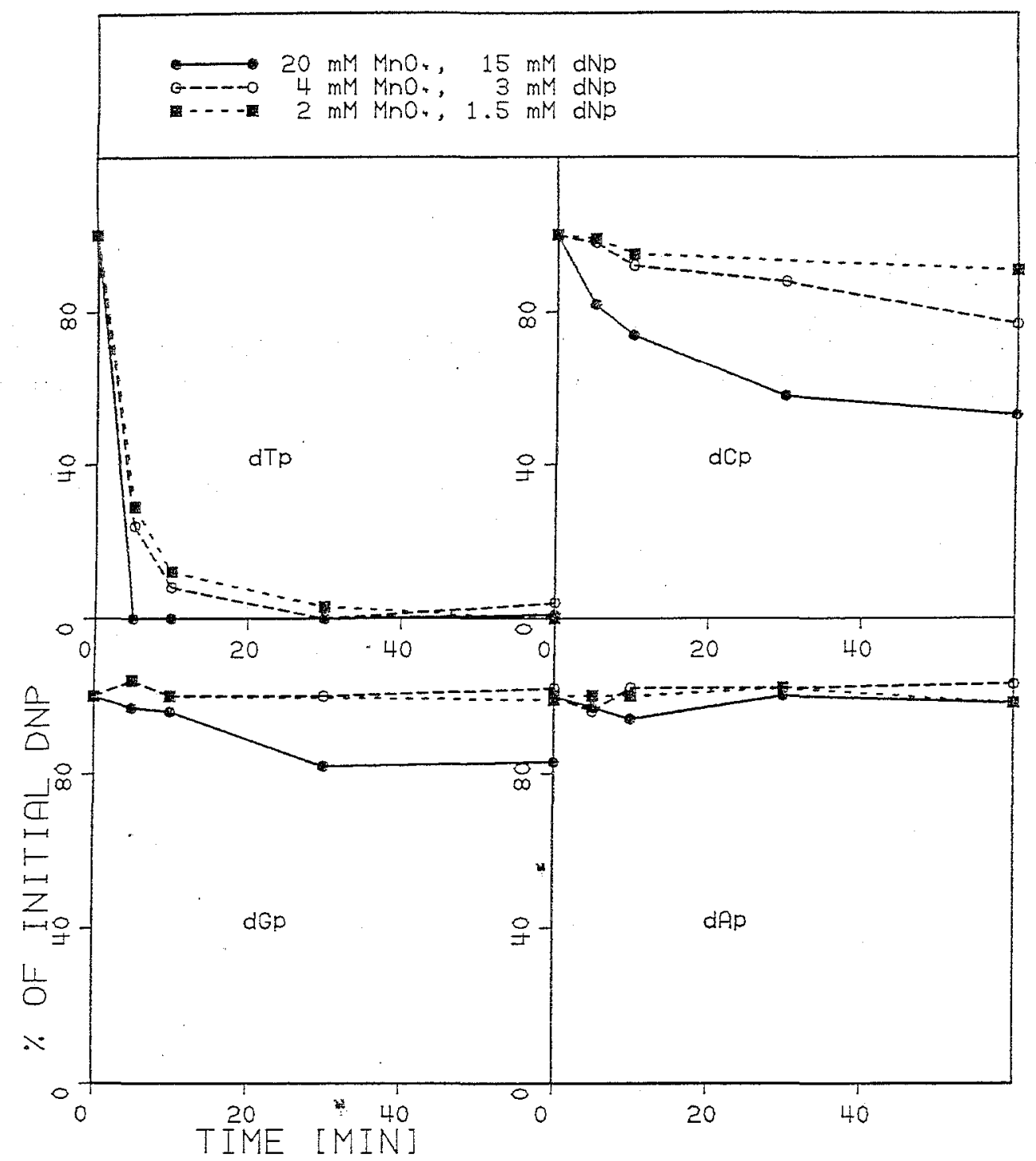

Fig. 1. Sensitivity of deoxyribonucleotides towards oxidation with $\mathrm{KMnO}_{4}$ at $0{ }^{\circ} \mathrm{C}$ for various periods of time. $d T p$, thymidine monophosphate; $d C p$, deoxycytidine monophosphate; $d G p$, deoxyguanosine monophosphate; $d A p$, deoxyadenosine monophosphate

Table 1. Molar fraction and relative amount of nucleotides after oxidation for $48 \mathrm{~h}$ at $37^{\circ} \mathrm{C}$ of doublestranded DNA with $\mathrm{H}_{2} \mathrm{O}_{2}$. The least sensitive nucleotide dAp, was set to $100 \%$. Oxidation. of $\mathrm{dAp}$ cannot be excluded on the basis of these results.

\begin{tabular}{|c|c|c|c|c|}
\hline \multirow[t]{2}{*}{$\mathrm{dNp}$} & \multicolumn{2}{|l|}{ Control } & \multicolumn{2}{|c|}{$1 M \mathrm{H}_{2} \mathrm{O}_{2}$} \\
\hline & $\begin{array}{l}\text { Molar } \\
\text { fraction }\end{array}$ & $\begin{array}{l}\text { Relative } \\
\text { amount }(\%)\end{array}$ & $\begin{array}{l}\text { Molar } \\
\text { fraction }\end{array}$ & $\begin{array}{l}\text { Relative } \\
\text { amount }(\%)\end{array}$ \\
\hline $\mathrm{dTp}$ & 0.22 & 100 & 0.24 & 62 \\
\hline $\mathrm{dCp}$ & 0.28 & 100 & 0.14 & 46 \\
\hline $\mathrm{dGp}$ & 0.28 & 100 & 0.24 & 78 \\
\hline $\mathrm{dAp}$ & 0.22 & 100 & 0.39 & 100 \\
\hline
\end{tabular}

dTp, thymidine monophosphate; $\mathrm{dCp}$, deoxycytidine monophosphate; $\mathrm{dGp}$, deoxyguanosine monophosphate; dAp, deoxyadenosine monophosphate 


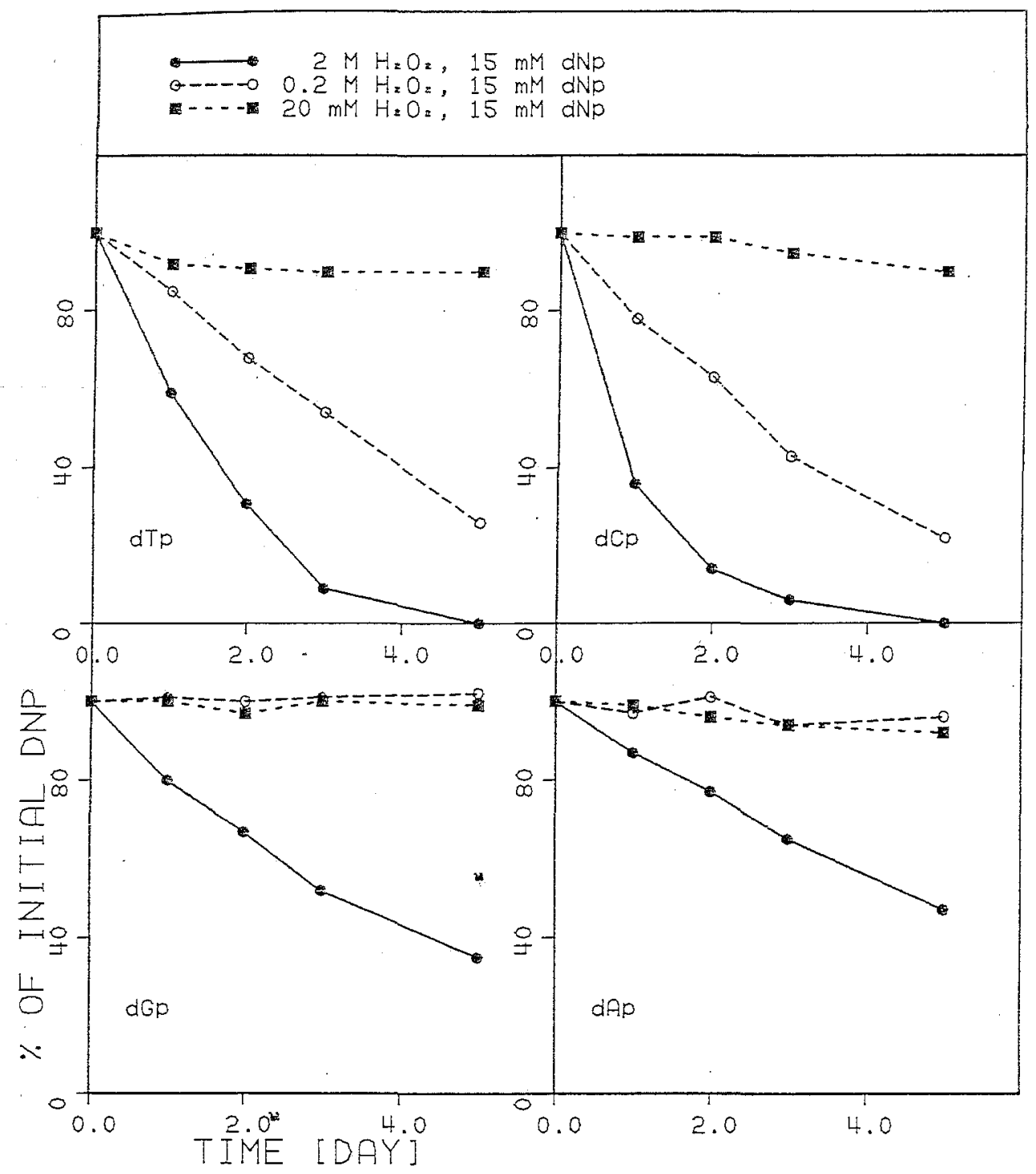

Fig. 2. Sensitivity of deoxyribonucleotides towards oxidation with $\mathrm{H}_{2} \mathrm{O}_{2}$ plus $25 \mu M \mathrm{Fe}^{3+}$ at $37^{\circ} \mathrm{C}$ for various periods of time. $d T p$, thymidine monophosphate; $d C p$, deoxycytidine monophosphate; $d G p$, deoxyguanosine monophosphate; $d A p$, deoxyadenosine monophosphate

dried in vacuo, and dissolved in $8 \mathrm{mMCaCl}$ and $20 \mathrm{mM}$ sodium succinate, $\mathrm{pH}$ 6.0. Digestion to nucleotides was performed with $2.5 \mathrm{U}$ micrococcal endonuclease (EC 3.1.31.1, Sigma) and 0.05U spleen exonuclease (EC 3.1.16.1, Boehringer Mannheim, FRG; Rotkreuz, Switzerland) for $16 \mathrm{~h}$ at $37^{\circ} \mathrm{C}$.

\section{Separation of Oxidation Products}

The nucleotides were separated by HPLC on a Lichrosorb RP18 $(7 \mu \mathrm{m})$ column $(4.2 \mathrm{~mm} \times 250 \mathrm{~mm}$ ), eluting at a flow of $1.5 \mathrm{ml} / \mathrm{min}$ with $50 \mathrm{~m} M$ sodium phosphate buffer, $\mathrm{pH} 5.8$, containing $3 \%$ methanol for $5 \mathrm{~min}$, followed by a linear gradient to $20 \%$ methanol in $10 \mathrm{~min}$. 


\section{Isolation of Thymidine Glycol}

The reaction products of the oxidation of $\left[{ }^{14} \mathrm{C}\right]$ thymidine were separated on a Lichrosorb RP18 $(7 \mu \mathrm{m})$ column $(4.2 \mathrm{~mm} \times 250 \mathrm{~mm})$, eluting at a flow of $0.75 \mathrm{ml} /$ min with $1 \%$ aqueous methanol for $15 \mathrm{~min}$, followed by a linear gradient to $100 \%$ methanol in $5 \mathrm{~min}$.

\section{GC/MS Analysis}

The reaction products were silylated in $0.2 \mathrm{ml}$ pyridine with $0.5 \mathrm{ml} \mathrm{N}$,O-bis(trimethylsilyl)trifluoroacetamide for $30 \mathrm{~min}$ at $150^{\circ} \mathrm{C}$. Pyridine was blown off with nitrogen and the residue dissolved in hexane; $1 \mu l$ was injected on a capillary column $(19 \mathrm{~m} \times 0.32 \mathrm{~mm})$, coated with SE-54 (film thickness, $0.10 \mu \mathrm{m})$. Elution was at $60 \mathrm{kPa} \mathrm{He}$, at a temperature of $60^{\circ} \mathrm{C}$ for $2 \mathrm{~min}$, followed by a gradient of $10^{\circ} \mathrm{C} / \mathrm{min}$.

\section{Results}

\section{Sensitivity of Nucleotides}

Figs. 1 and 2 show that the pyrimidines (top) were more sensitive than the purines (bottom), both with $\mathrm{KMnO}_{4}$ (Fig. 1) and $\mathrm{H}_{2} \mathrm{O}_{2}$ (Fig. 2). After 20 min incubation with $20 \mathrm{mM} \mathrm{KMnO}_{4}$, a reduction of the optical density to $10 \%$ and $80 \%$ was observed for thymidine monophosphate and cytidine monophosphate, respectively, whereas no reduction was detectable for the purines. With $20 \mathrm{mM} \mathrm{H}_{2} \mathrm{O}_{2}$, no effect was detectable at all. Only after 2 days of incubation with $0.2 \mathrm{M} \mathrm{H}_{2} \mathrm{O}_{2}$ was a reduction to $70 \%$ and $60 \%$ observed for thymidine monophosphate and cytidine monophosphate, respectively. No oxidation of the purines was detectable at this $\mathrm{H}_{2} \mathrm{O}_{2}$ concentration.

\section{Oxidation Products of Thymidine}

Oxidation of $\left[{ }^{14} \mathrm{C}\right]$ thymidine with $20 \mathrm{mM} \mathrm{KMnO}_{4}$ yielded only one product, which was identified by mass spectrometry as thymidine glycol. With $2 \mathrm{M} \mathrm{H}_{2} \mathrm{O}_{2}$, at least three different products could be detected. Thymidine-5,6-glycol represented about $30 \%$ of the products. Fragmentation by mass spectrometry of another product was compatible with 5-hydroxy-5-methyl-hydantoin deoxyriboside. This compound has been postulated by Teoule and Cadet (1971) as a possible product of thymidine irradiation.

\section{Sensitivity of $D N A$}

Single-stranded (ss) and double-stranded (ds) DNA was oxidized with $\mathrm{H}_{2} \mathrm{O}_{2}$ and the loss of optical density at $254 \mathrm{~nm}$ was taken as a measure of the damage. It was shown that single-stranded DNA was more sensitive to oxidation than double-stranded DNA. Incubation with $2 \mathrm{M} \mathrm{H}_{2} \mathrm{O}_{2}$ resulted in a time-dependent decrease of optical density. After 2 days with $2 \mathrm{M} \mathrm{H}_{2} \mathrm{O}_{2}$, the optical density was 
reduced to $30 \%$ and $70 \%$ for sSDNA and dsDNA, respectively. The sensitivity of the four nucleotides in intact DNA was $d C p>d T p>d G p>d A p$, i.e., the same ranking as found with isolated nucleotides (Table 1). The yield of high-molecular, oxidized DNA decreased with increasing concentration of $\mathrm{H}_{2} \mathrm{O}_{2}$. Under the present incubation conditions, only $30 \%$ of the DNA could be retained during dialysis. The loss is thought to be due to strand breaks.

\section{Discussion}

Thymine was not the most sensitive target base for an oxidation by hydroxyl radical in this in vitro system. A quantification of thymidine glycol must therefore lead to an underestimation of the DNA damage mediated by the hydroxyl radical. $\mathrm{H}_{2} \mathrm{O}_{2}$ was found to be an astonishingly mild DNA oxidizing agent in vitro and it is questionable whether, in vivo, base hydroxylations occur to a relevant extent. The hypothesis of an oxidative stress as one possible genotoxic process in carcinogenesis must be carefully examined and the relative importance of strand breaks and DNA hydroxylations has to be assessed in vivo.

Acknowledgement. This work was supported by the Swiss National Science Foundation (SNF Grant no. 3.626-0.84).

\section{References}

Cerutti PA (1981) Measurement of thymidine damage induced by oxygen radical species. In: Friedberg EC, Hanawalt PC (eds) DNA repair. Decker, New York, pp 57-68

Frenkel K, Goldstein MS, Duker NJ, Teebor GW (1981) Identification of the cis-thymine glycol moiety in oxidized deoxyribonucleic acid. Photochem Photobiol 4:963-969

Teoule R, Cadet J (1971) Radiolysis of thymidine in aerated aqueous solution. $J$ Chem Soc Chem Commun 1971:1269-1270 